\title{
Commentary
}

\section{Soft Islamophobia}

\author{
Namira Islam \\ Muslim Anti-Racism Collaborative (MuslimARC), PO Box 577, Southfield, MI 48037, USA; \\ namira@muslimarc.org
}

Received: 3 August 2018; Accepted: 12 September 2018; Published: 15 September 2018

\begin{abstract}
This article explores Islamophobia as a system of oppression by examining policies and practices found in liberal or left-leaning "anti-Islamophobia" spaces in the United States that limit the efficacy of the fight for justice. These include the reification of "Muslim" as a cultural category of brown foreigners, the lack of structural analysis around anti-Muslim hate, and the discomfort with and erasure of Islam as a faith in favor of "cultural" Muslims. The article then briefly proposes alternate ways forward that center the Muslims most affected by the intersections of race, class, gender, and religion in work against Islamophobia so that advocates can more effectively and directly address a system of Islamophobia.
\end{abstract}

Keywords: Muslims; Islam; Islamophobia; racism; narrative; social justice; culture; United States; advocacy; allyship

\section{Introduction}

In 2017, I was the fifth Muslim speaker to present at a convening where dozens of people had gathered from across the country to discuss ways in which we could combat anti-Muslim hate. I was the first to reference scripture. During the Q\&A and after heading back to my seat, the non-Muslim clergy in the room were enthusiastic to cite their own holy texts and build upon the conversation that my bringing up Qur'an had started. I found the entire experience both frustrating and humorous-despite organizers choosing to center Muslims, the agenda included no time for any of the daily prayers and there was no space designated for prayer for the Muslim attendees.

Islamophobia was the focus. Islam was an afterthought.

Unfortunately, this reflects an issue that occurs in multiple spaces in our current climate. Islamophobia, also sometimes labeled "anti-Muslim hate", refers to the long-standing system of discrimination that is enshrined in law and policy to specifically target those who practice the Islamic faith, i.e., individuals who are known as Muslims. Islamophobia "target[s] people or property associated, or perceived to be associated with Muslims". (OSCE 2017). In this paper, I will be specifically discussing trends within liberal spaces, i.e., those spaces where advocates are generally supporters of the Democratic Party and endorse public spending on programs such as education, health care, and economic inequality. These individuals are supporters of social justice and are attempting to push back against various forms of discrimination against minorities within the United States (Krugman 2017).

There are three distinct issues with how well-intentioned liberal allies are addressing Islamophobia. First is the lack of structural analysis around anti-Muslim hate. Second is the transformation of "Muslim" into a cultural category akin to any other ethnic or cultural group, despite this identity—and the animus targeting it—centering around faith. Lastly, there is a discomfort with Islam as a faith and an erasure of Islam as a faith that includes guidance on issues of exploitation and oppression.

Together, these issues damage Muslim communities and slow down the fight against structural racism. Hate crimes are on the rise against those who are perceived to be Muslim. Social media 
is playing a different role, with one study finding that President Donald J. Trump's "tweets on Islam-related topics are highly correlated with anti-Muslim hate crime after, but not before the start of his presidential campaign, and are uncorrelated with other types of hate crimes". (Müller and Schwarz 2018 , p. 1). Systems of surveillance, deportation, detention, and mass incarceration continue to target and harm Muslims and those perceived to be Muslim. There are specific methods that academics, organizers, activists, non-profit leaders, clergy, students, and others can utilize in order to avoid further entrenching Islamophobia. By examining the links between Islamophobia and other distinct systems of oppression, advocates can determine more efficient, targeted ways of dismantling these oppressive policies. Anti-Islamophobia work in the United States can and should draw upon the strengths of increased diversity and inclusion that better reflect American Muslim communities.

In this piece, I draw upon numerous sources, including relevant articles and media; informal interviews with academics, organizers, and activists; social media and other online forum discussions; and first-hand experience within community organizing spaces across the United States over a period of four years to provide commentary on developing trends in anti-Islamophobia advocacy.

\section{2. "Brown" and Foreign as a Cultural Category}

Islamophobes often ask how their rhetoric could be racist if "Muslim" refers to those who follow a faith tradition and not to those who are of a certain racial background. In the same breath, however, many Islamophobes stereotype all Arabs as Muslims and all Muslims as Arabs. In a 2014 study of over one thousand films, Jack Shaheen "documents the tendency to portray Muslim Arabs as Public Enemy \#1—brutal, heartless, uncivilized Others bent on terrorizing civilized Westerners". (Shaheen 2014, p. 8). In reality, globally, over 60\% of Muslims are of Asian background (Cornell University Library 2018).

Thus, Islamophobia builds upon concepts like nativism (Scholastic n.d.) and xenophobia (UNESCO n.d.), where Islamophobes point to Islam as a "foreign" belief system that is considered dangerous in part due to it being "un-American". This is shown in how readily the stereotypes regarding national origin and citizenship play a role in who Islamophobes have targeted. Non-Muslims who are "perceived to be Muslim" have been attacked or discriminated against in places of worships, in communities, and in places of public transit. Islamophobes have frequently uttered statements like "go back to your country" or other common anti-immigrant talking points.

These attacks have included people who are Sikh, Christian and Arab, Christian and African, and other non-Muslim South Asians, Latinos, and African-Americans. Below are four examples of such occasions where Islamophobes have harassed non-Muslims who fell within their stereotype of "foreign" and "Muslim" and therefore a terrorist:

- In November 2015, Kayla Gerber, a 24-year-old non-Muslim actress, singer, dancer, and one-time finalist in Miss Canada National, was assaulted by a man who "pinned her against a wall" and screamed at her to "take off [her] $\mathrm{f}^{* * * *} \mathrm{n}$ hijab and get the $\mathrm{f}^{* *} \mathrm{k}$ out of his country" (Haines 2015). Gerber is Jamaican-Canadian and "had wrapped her scarf around her head to keep her ears warm" (The Caribbean Camera Inc. 2015).

- In December 2015, an "older, white man" harassed Juan Calero, a 21-year-old non-Muslim Latino NYU student, calling Juan "a terrorist" and telling him "to leave the country". NBC News reported that Calera said that he "is not Muslim, but is often mistaken as one because of his beard and curly hair" and that this was the fourth time he had experienced anti-Arab and anti-Muslim harassment (Akbar 2015).

- In 2016, Laolu Opebiyi, a British Nigerian Christian man, experienced a phenomenon labeled "flying while Muslim" on an EasyJet flight when he was "removed from a plane by armed police at Luton airport after a fellow passenger read a message on his mobile phone about 'prayer' and reported him as a security threat". "Flying while Muslim" colloquially refers to the act of being profiled or harassed by another passenger, airline staff, or security personnel for being perceived to be Muslim during air travel, possibly resulting in removal from a plane or disruption to a booked flight (NPR 2018). Opebiyi was texting on his phone in a "conference call prayer group, 
which was [titled] 'ISI men' - an acronym for 'iron sharpens iron', from the Bible quote 'As iron sharpens iron, so one person sharpens another'." (Biblica, Inc. 2011).

- In 2017, a "routine trip to a strip mall in Canada almost turned deadly for a [non-Muslim] Latino family when Mark Phillips, baseball bat in hand, approached Sergio Estepa, Mari Zambrano, their 13-year-old son and a friend, informing them that they were under arrest for being 'ISIS terrorists'." (Rosario 2017). In footage filmed by Zambrano, Phillips is heard shouting, "Terrorist. Terrorist. We have a French terrorist here" in response to the family speaking Spanish and then "'ISIS! ISIS! We have ISIS right here', referring to the militant group Islamic State in Iraq and Syria". Estepa sustained injuries, including "a cracked rib and large bruise" in the attack and Phillips was arrested and "charged with aggravated assault and three counts of assault with a weapon". (Dubinksi 2017).

In these incidents, visual markers of faith—like a headscarf, beard, and texts about prayer-and perceived indicators of ethnic background or national origin played a role in how these non-Muslim individuals were treated. In incidents that have targeted South Asians and Middle Easterners who are non-Muslim, turbans, long beards, and language have played a role (Basu 2016).

However, in many spaces across the United States, advocates position "Muslim" in a similar cultural category in a manner similar to Islamophobes by conflating Middle Eastern or South Asian background with Muslim identity. Despite visual indicators of faith-whether from the Islamic faith or a different faith-playing a role in Islamophobia, anti-Islamophobia advocates often do not reject broad categorizations that all Muslims are "'brown' and foreign".

Instead, mainstream representation frequently focuses on Arab and South Asian Muslims while excluding or under-representing the experiences of Black Muslims (especially African-American Muslims), Latino/Hispanic Muslims, East Asian Muslims, and white Muslims. Assimilation into the United States-a topic that centers an immigration framework by suggesting Muslims are new to this country or to American culture-is frequently a talking point for telling American Muslim stories, with journalists framing it as "American culture often presents two opposing paths for young Muslims". (Green 2017). Debates over whether Muslim identity is "compatible" with American identity continue even though American Muslims are ethnically diverse with no clear racial majority. At least $20 \%$ of American Muslims are African-American and the fastest growing religious group in the United States is Latino Muslims, with up to $8 \%$ of American Muslims identifying as Latino (Pew Research Center 2017).

However, since the 2016 election, I and other advocates have observed multiple activists, organizations, and groups include only South Asian or Middle Eastern representation for the Muslim perspective in panels, media appearances, or reports that include communities who are under increased attack during the Trump administration. These panels often also include non-Muslim voices from Black, Latino, and East Asian backgrounds, reinforcing that a Muslim is someone who comes from a Middle Eastern or South Asian background. Thus, even though many West, Central, and South Asians are not Muslim — and many Blacks, Latinos, and East Asians are Muslim—these panels reinforce the silos that white supremacy has created about non-white identities: "Pick one".

This false equivalence presented between Muslim identity and Middle Eastern/South Asian identity occurs in non-profit funding, national convening spaces, government agency task groups, and in media coverage. Agencies and working groups utilize terms like "MASA" (Muslim, Arab, South Asian) and "AMEMSA" (Arab, Middle Eastern, Muslim, South Asian) to describe communities that are impacted by Islamophobia despite the number of incidents in which someone who is "perceived to be Muslim" - and is therefore subject to Islamophobia-is a non-Muslim African, Latino/Hispanic, Native American/indigenous person, or multi-racial. The terms MASA or AMEMSA therefore do not adequately capture the wide range of groups that are impacted by Islamophobia, especially when these groups are distinctly American communities and not from abroad. The omission is glaring because the first Muslims on American shores were enslaved Africans who were subject to policies that targeted their existing faith practices, including Islam (Beydoun 2014). Additionally, 
the most widely known American Muslims—individuals such as Malcolm X, Muhammad Ali, Kareem Abdul Jabbar, and others-are Black Muslims. In 1959, Mike Wallace and Louis Lomax produced a documentary with coverage of the Nation of Islam, titling it "The Hate that Hate Produced", with Wallace reporting that "the message of the play, is that the white man has been put on trial for his sins against the black man. He has been found guilty. The sentence is death. The play is sponsored, produced, by a Negro religious group who call themselves "The Muslims"." (McPhail 2002). Wallace would later note that "actually it was the first time that the Black Muslims came to the attention of White America". (Washington University Digital Library 1988, p. 125). This history should deepen how advocates understand-and challenge-Islamophobia today.

As Margari Hill, the Managing Director of the Muslim Anti-Racism Collaborative (MuslimARC), notes:

The effect of using Muslim as a cultural identity includes reifying South Asian and Arab hegemony in Muslim discourses. One particular issue is using "Arab and South Asian" as a synonym for Muslim, or in a grouping that is intended to be open to all Muslims but only uses some names and ethnicities. [ ... ] [T] he cultural category has resulted in the exclusion of Black Muslims in the discussion of Muslim civil liberties or the effects of Islamophobia. Black American Muslims have been under surveillance and discrimination many decades before 9/11. (Hill 2015b).

These silos that result in centering "Muslim" as a cultural identity similar to other cultural identities are thus creating an artificial paradigm for advocates. Terms and organizing structures like "MASA" or "AMEMSA" leave out impacted communities, further cement inaccurate stereotypes about Muslim foreignness, and split anti-Islamophobia organizing away from Black, Latino, and indigenous anti-racism organizing, because Islam and Muslims are separated from Black and Latino community priorities, despite how Black and Latino Muslims and non-Muslims are impacted when they too are perceived to be Muslim. American Muslim communities could greatly benefit in the work to challenge Islamophobia by increasing partnership with other American non-white communities who are addressing structural racism, anti-Blackness, and anti-immigrant sentiment, since these all stem from white supremacist narratives about who is American and who belongs in the United States.

Since Muslims are the second most diverse faith group in the United States (Lipka 2015), an average American Muslim space should have representation from all different racial backgrounds and therefore provide an intersectional lens to Muslim-led community organizing. Instead, there is division even within Muslim communities, where the impacts of policy and narratives that pit non-white groups against each other play out despite faith tying American Muslims communities together. Anti-blackness within the Muslim space results in silence and apathy about racist policies, the perpetuation of "good immigrant, bad immigrant" narratives results in support for anti-Latino sentiment, and xenophobia leads to a disregard for foreign policy impacts on countries abroad. These all play a role in the fractures among American Muslim communities (Hill 2015a). The Muslim Anti-Racism Collaborative (MuslimARC), founded in 2014, was created in part specifically to address these divisions. It has worked with over 12,000 individuals in 40 cities across the United States through workshops, lectures, panels, and other sessions that begin to educate communities about systemic racism, critical anti-Islamophobia activism, and the history of colonialism and global white supremacy. This response highlights how much work there is to be done on creating new avenues for political education and unity.

\section{More than Roses and Meet-And-Greets to Fight Islamophobia}

The first issue with how many advocates currently address Islamophobia is the lack of analysis around Muslim identity. The second is the lack of understanding around systems of discrimination.

New resources are beginning to provide a deeper analysis about what "Islamophobia" is and is not. In particular, American Islamophobia, by critical race scholar Khaled Beydoun (2018), 
and the \#IslamophobiaIsRacism syllabus by Su'ad Abdul-Khabeer, Arshad Ali, Evelyn Alsultany, and others, begin to approach Islamophobia from a structural lens that centers critical race theory. The \#IslamophobiaIsRacism syllabus authors argue that "anti-Muslim racism" is a more accurate term to use than Islamophobia:

This syllabus reframes "Islamophobia" as "anti-Muslim racism" to more accurately reflect the intersection of race and religion as a reality of structural inequality and violence rooted in the longer history of US (and European) empire building. ... It also connects the histories of various racial logics that reinforce one another, including anti-Muslim racism, anti-Black racism, anti-Latinx racism, anti-Arab racism, and anti-South Asian racism.

By focusing on understanding Islamophobia as anti-Muslim racism, this syllabus challenges the idea that the problem is one of individual bias and that simply knowing more about Islam will necessarily lead to a decrease in anti-Muslim racism. (Abdul Khabeer 2018).

Others have suggested different terms as well, but whichever term is utilized, Islamophobia is not simply about interpersonal disagreements between Muslims and non-Muslims, or about a "fear" of Muslims that non-Muslims act on. As mentioned, Islamophobia refers to the long-standing system of discrimination that is enshrined in law and policy to specifically target those who practice the Islamic faith, i.e., individuals who are known as Muslims.

On the right-leaning end of the political spectrum, Islam as a religion is posited as fundamentally incompatible with Western values and a threat to the United States and other "enlightened" nations. Islamic law is described as "sinister" or \#creepingsharia (Posner 2011), "barbaric", and "rigid", and the religion itself is commonly portrayed as a political affiliation more than a bona fide faith (Elliott 2011).

A 2011 report published by the Center for American Progress entitled "Fear, Inc." explored the "roots" of the "Islamophobia network" in the United States and concluded that:

A small group of foundations and wealthy donors are the lifeblood of the Islamophobia network in America, providing critical funding to a clutch of right-wing think tanks that peddle hate and fear of Muslims and Islam-in the form of books, reports, websites, blogs, and carefully crafted talking points that anti-Islam grassroots organizations and some right-wing religious groups use as propaganda for their constituency. Some of these foundations and wealthy donors also provide direct funding to anti-Islam grassroots groups. ... Altogether, ... seven charitable groups provided $\$ 42.6$ million to Islamophobia think tanks between 2001 and 2009. (Ali 2011).

The report further found that Islamophobia think tanks were a "key source" of Islamophobic talking points for "right-wing politicians, pundits, and grassroots organizations", including individuals like former Speaker of the House of Representatives Newt Gingrich. The think tanks provided these individuals and organizations "with a steady stream of reports mischaracterizing Islam and warnings about the dangers of Islam and American Muslims". (Ali 2011, p. 3). In 2015, the Center for American Progress published "Fear, Inc. 2.0", noting that both reports "reveal how a well-funded, well-organized fringe movement can push discriminatory policies against a segment of American society by intentionally spreading lies while taking advantage of moments of public anxiety and fear". (Duss 2015, p. 2).

Thus, these Islamophobic narratives are drafted and amplified into the mainstream by a million-dollar industry (Rifai 2016). The prevalence of these narratives leads to buy-in for the enactment of policies like the PATRIOT Act, the War on Terror (Watson Institute for International \& Public Affairs n.d.), no-fly lists, indefinite detention in Guantanamo Bay (Fox 2018), "Countering Violent Extremism" CVE programs, and the Muslim Ban (ACLU of Washington n.d.), which have collectively had a devastating impact (Anderson et al. 2017) on American Muslims and Muslims abroad. The narratives dehumanize (Maiese 2003) Muslims-likening Muslims to "vermin" or a "cancer" or some other non-human entity (Clark 2014) because of an "allegiance" to Islam —and the resulting policies are often indiscriminate in 
who they harm, targeting civilians and children, since, under these narratives, all Muslims are seen as less than human and therefore justifiable targets to keep those who are seen as human safer. As noted in contextualizing the 2018 Supreme Court decision upholding the Trump administration's travel ban:

Suspicion of Muslims guides our foreign policy: Teenagers and other civilians across the Middle East have been killed or seriously injured by US drone strikes and bombs (Watson Institute for International \& Public Affairs n.d.). Due to the decades-long War on Terror, US drones have killed civilians at weddings (Almasmari 2013) and taught young children to fear the sky. And civilians living in at least five of the countries that are on the Muslim Ban list have been or are currently on the receiving end of US bombs and airstrikes (Mohdin 2017). The US justifies this violence based on the narrative that all Muslims are inherently prone to "terror" and that civilian casualties are just the price we need to pay for national security.

Our nation denies the Muslim men still being held at Guantanamo Bay (Fox 2018)—men who were never charged with a crime- - the right to a trial. When Trump was elected, progressives everywhere feared he would implement a "Muslim registry", a policy that already happened after 9/11 when some immigrants from 24 majority-Muslim countries were required to register and regularly check-in (Lind 2016) with government officials. The program, called the National Security Entry-Exit Registration System, or NSEERS, helped the government fine, arrest, and deport Muslims. Today, Muslims are among those that ICE rounds up for deportation. This past Ramadan, Somali Muslim immigrants were hindered from freely practicing their faith while detained in an ICE facility in Florida (Saleh 2018). (Islam 2018a).

A common talking point for Islamophobes is that anyone who becomes Muslim or is born Muslim is currently a terrorist or will someday become a terrorist through exposure to the "true teachings" of Islam, which, they argue, are antithetical to American, European, or Western values. Many liberal advocates-whether they are Muslim or non-Muslim —often accept this framework by setting out to disprove or debate the talking points about Muslims instead of deconstructing and rejecting the talking points altogether. This is apparent in the embrace of stories of Muslim soldiers and veterans (Wright 2016), the centering of narratives about Muslim doctors (McCrummen 2017; Warikoo 2017) and "badass" Muslim women (Sanchez 2017; Abdelrahman 2017). Additionally, the amplification of stories where Muslims are giving (Rozen 2017) in charity (Soubry and Streeting 2017) or "breaking stereotypes" (Guthrie 2017) by getting along with Christians, Jews, or the queer community are utilized to disprove talking points as if giving in charity or building interfaith relationships are newsworthy or extraordinary when Muslims are involved instead of routine, everyday occurrences for the world's 1.5 billion Muslims.

The embrace of Muslims by non-Muslim liberals—as demonstrated by the most recent Democratic party messaging on the issue, for example-is still couched in terms of national security and compatibility with Western values (Beydoun 2016), except this time, everyday Muslims are "patriotic Americans", "good immigrants", "law-abiding citizens", and therefore "staunch allies" in the fight against "Muslim extremism". Even among liberal allies, American Muslim experiences are filtered within a "good Muslim, bad Muslim" narrative about who is joining the fight against terrorism. (Mamdani 2002). This continues to frame terrorism as a distinctly Muslim problem, one that needs to be resolved within the community, instead of a geopolitical problem that requires a more nuanced analysis.

Thus, when these advocates look to challenge Islamophobia, they often do not acknowledge the systematic nature of the issues at hand and instead focus their priorities on increased dialogue between Muslims and non-Muslims. This is done under the assumption that if only American non-Muslims understood their American Muslim neighbors, Islamophobia would lessen. This core theory not only centers the concerns of the "persuadables" (Islam 2018b) who are "misinformed" about Islam, but places the burden on American Muslims, who make up 1.1\% of the US population (Besheer 2018), to conduct outreach in as friendly and non-threatening a manner as possible to stop Islamophobia. 
Despite the increased number of hate crimes against Muslims and those perceived to be Muslim, and the devastating losses that Muslims worldwide have faced at the hands of terrorist groups like ISIS, these narratives place responsibility on Muslims to change hostile hearts and minds. American (and British and Australian and European) Muslims have handed out roses (Copoglu 2016), spent hours sitting outside with donuts to answer questions (Annear 2015), and published writing and art about American Muslim families and dreams and hopes in an effort to humanize Muslims.

However, a study of US history-especially African-American history-demonstrates that familiarity with public figures or individuals from marginalized backgrounds does not automatically translate into the dismantling of racist laws or systems. General support or interpersonal understanding does not translate to distinct law or policy on its own. Moreover, individuals can claim to support individual groups or communities while still executing harmful laws and policies. As an example, President Trump has claimed that he loves or gets along tremendously with "the Muslims" (Gray and Lee 2015) or "the Blacks" (CBS News n.d.) while simultaneously instituting discriminatory policies against Muslims around the world and against African-Americans since taking office.

Thus, narrative and interpersonal work must be coupled with policy and advocacy work to accomplish systemic change. From personal observation, while there are individuals and groups organizing against Islamophobia from a policy and advocacy lens, many of the people who are salaried to challenge Islamophobia on a policy level are non-Muslim white liberals or Muslims who self-label as "more culturally Muslim" than religious. Often, the Muslims who are grounded in faith-based community spaces are there pro bono to advise on the actions that the liberal groups will work on so that these actions are more respectful to Muslim communities. These individuals are sometimes grounded in mosques and other community spaces and are relied upon for access to Muslim American spaces but not given adequate resources to properly execute on outreach or educational campaigns. More research about these policy spaces against Islamophobia is needed to explore racial and religious demographics and properly determine the statistics. If needed, advocates could then begin to implement policies of diversity and inclusion in these anti-Islamophobia spaces to ensure that more funding is provided for those who are directly impacted, and that more salaried staff come from marginalized backgrounds.

Without a restructuring of resources, we will continue to have an environment where those most starkly in danger of Islamophobic vigilantes or government targeting are held at a distance by policy advocates when they seek to discuss how to organize against a system that spies, jails, deports, and ultimately destroys lives. This hesitation to center the Muslims who are most affected in a way that allows for those Muslims to truly lead—and be funded-to do the work for their communities, despite their lives depending on it, is still a function of Islamophobia. While this function may not be as harsh or dangerous as traditional understandings of Islamophobia, it is still dangerous and is thus something I have labeled "soft Islamophobia". Soft Islamophobia occurs when those who are most directly impacted by Islamophobia are systematically disenfranchised from the work that liberal organizations, individuals, and groups are leading to challenge Islamophobia. Soft Islamophobia ensures that those individuals are prevented from accessing financial resources, leadership spaces, and strategy sessions. Soft Islamophobia often transforms "Muslim" into a cultural category, centers the preferences of white "persuadables" on how they want to understand Islam, and dismisses the structural underpinnings of Islamophobia in favor of interpersonal dialogue that is focused on Muslims who "break the stereotypes" that are supplied by the Islamophobia narrative industry.

Thus, the narrative campaigns that are launched in response to Islamophobia fixate around "Muslims who are just like you", i.e., the typical American non-Muslim. This still allows space for narratives-and, thus, policies-that alienate and target the Muslims who are not like the typical American non-Muslim, i.e., those Muslims who are "too religiously conservative" or fail to meet another standard about who deserves protection from discrimination. This often includes Muslims who speak accented or broken English, Muslims who are low-income, and/or Muslims who have a criminal background. Thus, when narrative campaigns predominantly feature middle to upper class 
Muslims who are from white collar professions or are involved in law enforcement or national security work, larger issues of class, xenophobia, nativism, and our broken systems of immigration and mass incarceration play a role in leaving certain Muslims vulnerable to Islamophobia.

There is also a tension to include Muslims who are actively ritualistically religious or to allow Muslim leaders to draw on faith in deeper ways to support the anti-Islamophobia work that is happening. A clear example of this is how governmental CVE programs (Boyd 2016) seek to monitor and track whether someone is fasting more, praying more, attending religious lectures, keeping halal (the Islamic equivalent of keeping kosher or following specific dietary guidelines), growing a beard/wearing the headscarf, or learning how to speak Arabic. Increasing religiosity is still seen as a precursor to terror, since the underlying assumption that "Islam = dangerous" has not shifted despite people being more accepting of certain kinds of Muslims.

This leads to the third issue, the erasure of Islam as a religion that provides specific guidance on all avenues of life.

\section{When Faith Is Apparently Still the Problem}

Despite what Vice President Mike Pence may say (Jacobson 2018), Americans as a whole are in an era of increased distance (Jacobson 2018) from organized religion. People are unchurched (Rainer 2007), unsynagogued (Davidman 2007), untempled, and unmosqued (Eid 2014). Sentiments like "I'm spiritual, but not religious" are common, and many individuals express a discomfort with rituals and rites.

This widespread discomfort with engaging with religion or citing scripture in activist and organizing spaces is not shocking given the current climate. Today, those who are most often referencing religion in the news or in politics come from fundamentalist perspectives and backgrounds-whether that element is Christian (Blades 2017), Jewish (Berger and Khoury 2017), Buddhist (Strathern 2013), Hindu (Safi 2017), or Muslim. Many of these individuals are newsworthy especially because they are using religion to justify limiting the rights of others to life, liberty, or the pursuit of happiness, and their behavior is resulting in the death and suffering of innocent people.

Thus, those opposing these actions often eschew religion altogether (Cox 2017). The "religious left" (Jenkins 2017) may have scholars and clergy who deeply engage with scripture, but from personal observation and in speaking with other activists, in many liberal spaces, only generic references are made to religious sentiments, if any sentiments are included at all during these gatherings. Individuals in these spaces may include an opening prayer or reflection, references to interfaith harmony or "the golden rule", and mention religious holidays and multicultural neighborliness, but this is carried out in more of a superficial way. Individuals are hesitant to seek or host a deeper engagement with Islam, despite how many Islamophobic narratives claim to cite specific verses or events in Islamic history.

In this context, who is fighting Islamophobia-and how-sits within the tension of celebrating religious plurality while also being deeply uncomfortable with religion as a whole and Islam in particular. Thus, the focus pivots to Muslims as individuals in an attempt to disprove Islamophobic assertions about women, religious plurality, fundamentalism, and more, which cedes grounds to the think tanks and other organizations who consistently generate fear-mongering content about sharia law, among other religious topics.

When individual Muslims are the focus, Middle Eastern or South Asian Muslims who demonstrate Islamic religious practices in an Americanized way are often celebrated by mainstream media. For example, many well-known Muslim women role models in the news and popular culture today are trendy with hijab style (Khan 2012), wear full faces of makeup (Weiner 2017), and/or consistently use social media channels that often amplify aspects of hyper-individualistic celebrity culture, like Instagram. Fashion companies who choose to exploit Muslim women's labor outside of the United States to make their products have hired American Muslim women models who wear the headscarf to market their products. (Sanghani 2016). While this is lauded as positive messaging against 
Islamophobia, it still leaves the door open to negative narratives about Muslim women who may still be considered oppressed or fundamentalist because they do not wear makeup, do not pin their headscarf in a particular style, or who speak out against unethical business practices in the fashion and beauty industries. Research is needed on this topic of American Muslim women in the context of soft Islamophobia.

In contrast to the politics around the hijab and Muslim women's modesty, the stories of Muslims who embrace their "Muslim heritage" (Kloub 2016) but not Islamic tenets (Nomani 2015) are also centered and amplified in an effort to push back against Islamophobic narratives. By talking about eating pork (Kid 2013), drinking alcohol (Diab 2018), not praying/fasting, that Muslim is seen as a non-threat since Islam is not a part of their life. It is a function of soft Islamophobia if the only Muslims who are granted space in mainstream publications and broadcast television are those who have distanced themselves from the faith.

Additionally, under this belief that all religious institutions are oppressive-and Islamic religious institutions are threatening in particular-Muslims who are holidays-only "spiritual" practitioners or "cultural Muslims" are often covered by media outlets. For example, Ramadan has been framed like Christmas (Khalil 2014), with the commercialization of crescent-shaped trees, advent calendars, greeting cards, and Party City decorations (Salam 2018).

While these stories do not necessarily harm the fight against Islamophobia and certainly do amplify the voices of a wide range of Muslims, they also do not address the core of Islamophobia messaging and policy, which specifically targets those who visibly appear to be Muslim or who are increasing their ritualistic worship on a more frequent level. Governmental CVE programs are not interested in bacon-eating, alcohol-drinking Muslims. Surveillance programs are tied to the mosque and $\log$ who attends on a more regular basis.

Thus, there is still a positioning of "Muslim values" against "American values". With the increase of "spiritual" practitioners of religion on the political left and the dominance of the conservative practices of the religious right, softening the religious tenor of Islam is one way to become "American enough" to be safe in the eyes of both Islamophobes and liberals who are uncomfortable with religion.

This is also another reason why the transition of "Muslim" into a cultural category is so problematic. If Muslim is a cultural or ethnic category similar to any other racial/ethnic background, Muslims would be expected to show up on panel discussions or in the media with only the faintest mention of hadith, Qur'an, or Islamic history - these verses and stories and philosophies should be generic, feel-good, and inspirational, and the focus should be more about the individual Muslim and their life story. Through personal observation, I have noted how in multiple events, no other Muslim speaker even generically references Islamic theology. The focus is on Muslims as people and not on Islam as a faith. Islam is thus still seen as inherently dangerous and compatible in this country only if it is practiced in small doses.

Is it truly progress in anti-Islamophobia work to have an audience for this softer approach to Islam? In the end, this approach still creates an environment where Muslims are othered, surveilled, and profiled if they practice their faith. If liberals and conservatives alike-of all races and backgrounds-still "keep an eye" on the religious Muslims because of this unchanged belief that if anyone is going to go into a murderous path, it is going to be the religious one, what policy changes could possibly follow? By celebrating and amplifying the narratives of only the American Muslims that fit within liberal frameworks of who is a "good American", this leaves the Islamophobic frameworks intact to justify the targeting and harassment of other types of Muslims, both domestically and abroad.

\section{Conclusions}

Solidarity is about centering the most affected (Islam 2018c). Several Islamophobic attacks in recent years have impacted victims who are elderly, immigrant Muslims (Sidahmed 2016); young, African/Black Muslims (Carey 2017); low-income Muslims (Solis 2016); and/or women in hijab 
(Aziz 2011). These individuals are facing the intersections of race, class, gender, and religion and are left vulnerable when not included in leadership development, strategy sessions, funded organizing roles, narrative change work, or other opportunities due to the soft Islamophobia that does not think to include individuals from these demographics.

To intervene against soft Islamophobia and work more efficiently to dismantle the system of Islamophobia, advocates should consider the following 7 tactics and methods:

(1) Increase internal education and training on racial justice. By undergoing trainings on anti-racism organizing, cultural competency, and critical anti-Islamophobia activism, organizations and institutions will be better equipped to understand the structural underpinnings of Islamophobia. This means any campaigns can draw on wider historical memory and avoid strategies that may not get to the roots of organized Islamophobia.

(2) Strategically engage in solidarity practices. Advocates should work on challenging the structural underpinnings of anti-Blackness, xenophobia, and other oppressive forces that impact multiple communities. These forces affect different ethnic groups of Muslims, which limits the capacity of those groups to advocate for justice. Additionally, since these forces all stem from one specific foundation, by challenging them together, it will become easier to assess what tactics will work against Islamophobia specifically. More importantly, by undermining the institutions and systems that allow for Islamophobia to exist, Islamophobia will also lessen.

(3) Center the leadership and guidance of Muslims who are most likely to be targeted through violent policy and vigilante action. This can be done by conducting more community needs assessments, consulting with grassroots leaders in a more equitable manner, and ensuring that resources are provided to those who are on the front lines so that they can invest more of their time and energy into this work. Advocates should actively aim for more inclusion in the activism space for underrepresented Muslim voices-and not just millennial or 'woke' or 'cool' Muslims who are easily consumable by the general American public.

(4) Shift the narratives about Muslims in the media to also amplify the stories of Muslims who attend mosque events, are affiliated with a house of worship, and/or dress more conservatively. Focusing on the narratives of Muslims who are proudly unmosqued and have no connection to a house of worship is not the same as amplifying the voices of the loved ones of people who were killed while at the mosque (Page 2018) or capture the pain of those who have faced arson in their house of worship (Cuevas 2017). Additionally, focusing on liberal Muslimah media figures (Shukla 2016) or "culturally-Muslim" male (Mallenbaum 2017) comedians (Firestone 2017) does not mean that a serious-looking long-bearded man in a thobe (an ankle-length long-sleeved loose flowing outfit), or a woman wearing a niqab (face veil), is going to feel the benefits of that acceptance. These individuals are still seen as the "foreign" and dangerous risk. While those Muslim narratives may not be as "stereotype-breaking" (Global Fund For Women 2017), it is important that advocates hold a space for a truly diverse set of voices and include not just the voices that are currently included but also additional voices that are underrepresented.

(5) Improve the diversity in the room and work to ensure inclusion in those spaces. Cast a wider net that better reflect the racial demographics of American Muslims. Any anti-Islamophobia convening or gathering should include people who represent more of the variety of stories, priorities, and expertise that exist within the American Muslim space. Additionally, reach out to Muslims of all different backgrounds, and especially be more cognizant of inclusion for those who practice rituals of religion daily. The commercialization of faith practices-including Ramadan decorations in stores or hijabs/headscarves for sale in department stores-alone will not lead to better policies for all. That system of oppressive policies is already in place and it is critical for advocates to continue protecting religious plurality in the United States.

(6) Resist narrow and rigid classifications of which communities are impacted by Islamophobia. Push back against the idea of embracing "Muslim" as a cultural category and placing it in 
contrast to other categories like Black, East Asian, or Latino. "Muslim" is not a cultural category, and American Muslims come from all different ethnic backgrounds. Thus, indicators of religiosity—like the headscarf, a beard, or communications about prayer-often lead to people of all backgrounds being perceived as Muslim and therefore targeted. Since whether someone is "perceived to be Muslim" often rests on visual cues that stem from the practice of religious tenets, more focus is needed on learning about religion and not letting fundamentalism from other parties impact how we go about understanding Islam in America.

(7) Undertake a deeper historical analysis. Advocates should look further into the history of Islam in America, and review the deep, multi-century-long discussions about Islam, democracy, and interfaith societies that span the globe. More research is needed on Muslims in the United States, and especially on communities that have been here for generations, specifically examining their strategies and tactics for challenging discrimination.

In communities around the country, it is critical to the well-being of those who are most affected by Islamophobia that conversations grow deeper than superficial conversations about "diversity" or "multiculturalism". On a policy level, advocates should not consider the work against Islamophobia complete if an American-born Muslim woman is welcomed and celebrated but her immigrant mother still fears walking outside. The work is not complete if a Muslim cabdriver or mosque-goer or "auntie" or "uncle" wearing non-Western clothes is still at risk. The work is not complete while Muslim men are still detained in Guantanamo Bay despite never being formally charged or when drones are still being dropped on civilians abroad or when Black Muslims are political prisoners for their work. \#BlackLivesMatter applies to Muslims (MuslimARC 2014). Bangladeshi Muslim women garment workers are dying in fires (War On Want 2015) to sew trendy, "cheap" clothes that American Muslim women are modeling. The Rohingya (Al Jazeera 2018) are being slaughtered at the hands of Buddhists, and Latino Muslims are facing deportations (Kaleem 2017). Native American Muslims are still at Standing Rock (MuslimARC 2016). By understanding the ties between structural forces, advocates can begin to unravel the knots.

For claims that "Islam is not incompatible with Western values", advocates should instead interrogate how those Western values are being defined in the first place. Advocates should examine whether those who argue that they represent "Western values" are holding white supremacy, unchecked materialism, and militarism as the defining characteristics of the West. As a country, we continue to face crossroads where we can choose how we respond to those who embrace racism, poverty, and war as essential elements of what represents America. By understanding Islamophobia as a structural force that cannot be siloed from other forms of hate, advocates can begin to dismantle the oppressive systems that cause so much pain and suffering to millions domestically and abroad.

Funding: This research received no external funding.

Acknowledgments: Thank you to the MuslimARC national network for deepening the conversations around Islamophobia. To Margari Hill: my deepest gratitude for your leadership in deconstructing concepts and sharpening the analysis around Islam, Muslims, and advocacy in the United States. Lastly, thank you to Lejla Bajgoric for providing research and editing that made this work possible.

Conflicts of Interest: The author is the Co-Founder and Executive Director of the Muslim Anti-Racism Collaborative.

\section{References}

Abdelrahman, Hadiya. 2017. 5 Badass Muslim Women Who Have Led Feminist Movements around the World. Everyday Feminism, July 30. Available online: https:/ / everydayfeminism.com/2017/07/badass-muslimfeminists / (accessed on 29 July 2018).

Abdul Khabeer, Su'ad. 2018. Islamophobia is Racism: Resource for Teaching \& Learning about anti-Muslim Racism in the United States. April 4. Available online: https://islamophobiaisracism.wordpress.com/ (accessed on 29 July 2018).

ACLU of Washington. n.d. Timeline of the Muslim Ban. ACLU of Washington. Available online: https:/ /www.acluwa.org/pages/timeline-muslim-ban (accessed on 29 July 2018). 
Akbar, Farah. 2015. NYU Asks Students to Help Report Harassment Targeting Muslim Community. NBC News. NBC Universal Media, LLC. December 9. Available online: https://www.nbcnews.com/news/asianamerica/nyu-asks-students-help-report-harassment-targeting-muslim-community-n476581 (accessed on 29 July 2018).

Al Jazeera. 2018. Who are the Rohingya? Al Jazeera, April 18. Available online: https://www.aljazeera.com/ indepth/features/2017/08/rohingya-muslims-170831065142812.html (accessed on 29 July 2018).

Ali, Wajahat. 2011. Fear, Inc.: The Roots of the Islamophobia Network in America. Washington: Center for American Progress.

Almasmari, Hakim. 2013. Yemen Says U.S. Drone Struck a Wedding Convoy, Killing 14. CNN, December 13. Available online: https:/ /www.cnn.com/2013/12/12/world/meast/yemen-u-s-drone-wedding/index. html (accessed on 26 June 2018).

Anderson, Craig A., Muniba Saleem, Sara Prot, and Anthony F. Lemieux. 2017. Exposure to Muslims in Media and Support for Public Policies Harming Muslims. Communication Research 44: 841-69.

Annear, Steve. 2015. Coffee, Doughnuts, and a Muslim to Answer Your Questions. The Boston Globe, December 21. Available online: https://www.bostonglobe.com/metro/2015/12/21/couple-sets-askmuslim-booth-cambridge/aOiTfhSp8wtM5zYhqaWdnO/story.html (accessed on 29 July 2018).

Aziz, Sahar. 2011. Time to Address Violence against Muslim Women. Institute for Social Policy and Understanding, November 2. Available online: https:/ / www.ispu.org/time-to-address-violence-against-muslim-women/ (accessed on 29 July 2018).

Basu, Moni. 2016. 15 Years after 9/11, Sikhs Still Victims of Anti-Muslim Hate Crimes. CNN, September 15. Available online: https://www.cnn.com/2016/09/15/us/sikh-hate-crime-victims/index.html (accessed on 6 September 2018).

Berger, Yotam, and Jack Khoury. 2017. Jewish Extremist Leader in Israel Faces Charges of Incitement, Threats. Hareetz, November 13. Available online: https:/ / www.haaretz.com/israel-news/jewish-extremist-leaderfaces-charges-of-incitement-threats-1.5465176 (accessed on 29 July 2018).

Besheer, Mohamed. 2018. New Estimates Show U.S. Muslim Population Continues to Grow. Pew Research, January 3. Available online: http:/ / www.pewresearch.org/fact-tank/2018/01/03/new-estimates-show-u-s-muslimpopulation-continues-to-grow / (accessed on 6 September 2018).

Beydoun, Khal. 2014. Antebellum Islam. Howard Law Journal 58: 141. [CrossRef]

Beydoun, Khaled. 2016. The Myth of the 'Moderate Muslim'. Al Jazeera, May 20. Available online: https:/ / www. aljazeera.com/indepth/opinion/2016/05/myth-moderate-muslim-160511085819521.html (accessed on 29 July 2018).

Beydoun, Khaled. 2018. American Islamophobia: Understanding the Roots and Rise of Fear. Oakland: University of California Press Books.

Biblica, Inc. 2011. Holy Bible, New International Version. Available online: https:/ /www.biblegateway.com/ passage/? search=Proverbs+27\%3A17\&version=NIV (accessed on 29 July 2018).

Blades, Lincoln Anthony. 2017. Violent Extremists Can Be Christians, and It's Time We Talk about It. Teen Vogue, September 1. Available online: https:/ / www.teenvogue.com/story/violent-extremists-can-be-christiansand-its-time-we-talk-about-it (accessed on 29 July 2018).

Boyd, J. Wesley. 2016. The Dangers of Countering Violent Extremism (CVE) Programs. Psychology Today, July 19. Available online: https://www.psychologytoday.com/us/blog/almost-addicted/201607/thedangers-countering-violent-extremism-cve-programs (accessed on 29 July 2018).

Carey, Julie. 2017. 'You Killed My Daughter!' Slain Muslim Teen's Father Shouts at Suspect in Court. NBCUniversal, October 13. Available online: https://www.nbcwashington.com/news/local/HearingSet-for-Man-Charged-in-Muslim-girls-Death-450732843.html (accessed on 29 July 2018).

CBS News. n.d. 30 of Donald Trump's wildest quotes. CBS News. Available online: https:/ /www.cbsnews.com/ pictures / wild-donald-trump-quotes/12/ (accessed on 29 July 2018).

Clark, Liat. 2014. The 'Eight Faces' of Anti-Muslim trolls on Twitter. Wired UK, July 4. Available online: https: / / www.wired.co.uk/article/anti-muslim-twitter-trolls-study (accessed on 29 July 2018).

Copoglu, Sumeyye. 2016. Conquering People's Hearts with a Single Rose: “Hello, We're Muslims!”. Mvslim, March 17. Available online: http://mvslim.com/conquering-peoples-hearts-with-a-single-rose-hello-weremuslims / (accessed on 29 July 2018). 
Cornell University Library. 2018. Exhibition: Islam in Asia: Diversity in Past and Present: Muslim Populations. August 30. Available online: https:/ / guides.library.cornell.edu/IslamAsiaExhibit (accessed on 6 September 2018).

Cox, Daniel. 2017. Don't Bet on the Emergence of a 'Religious Left'. ABC News, April 20. Available online: https: / / fivethirtyeight.com/features/dont-bet-on-the-emergence-of-a-religious-left/ (accessed on 29 July 2018).

Cuevas, Mayra. 2017. Spate of mosque fires stretches across the country. CNN, March 2. Available online: https:/ / www.cnn.com/2017/03/02/us/mosque-fires-2017/index.html (accessed on 29 July 2018).

Davidman, Lynn. 2007. The New Voluntarism and the Case of Unsynagogued Jews. In Everyday Religion: Observing Modern Religious Lives. Edited by Nancy. T. Ammerman. New York City: Oxford University Press, pp. 51-67.

Diab, Khaled. 2018. A secular Muslim's guide to drinking alcohol during Ramadan. Washington Post, May 31. Available online: https://www.washingtonpost.com/outlook/a-secular-muslims-guide-to-drinkingalcohol-during-ramadan/2018/05/31/5b2fdf80-6449-11e8-a69c-b944de66d9e7_story.html?noredirect= on\&utm_term=.4acb5a3d756b (accessed on 29 July 2018).

Dubinksi, K. 2017. Man in southwestern Ontario charged after family attacked with bat amid shouts of 'ISIS'. CBC News, December 8. Available online: https:/ / www.cbc.ca/news/canada/london/family-attacked-batyelling-isis-st-thomas-1.4439437 (accessed on 6 September 2018).

Duss, Matthew. 2015. Fear, Inc. 2.0: The Islamophobia Network's Efforts to Manufacture Hate in America. Washington: Center for American Progress.

Eid, A. 2014. About Unmosqued the Movie. Available online: http://www.unmosquedfilm.com/about/ (accessed on 14 September 2018).

Elliott, Andrea. 2011. The Man Behind the Anti-Shariah Movement. The New York Times, July 30. Available online: https:/ / www.nytimes.com/2011/07/31/us/31shariah.html (accessed on 29 July 2018).

Firestone, Lonnie. 2017. How Aziz Ansari Explained His Bacon-Eating to His Devout Muslim Parents. Vanity Fair, June 7. Available online: https:/ /www.vanityfair.com/hollywood/2017/06/aziz-ansari-master-of-nonemoth-bacon (accessed on 29 July 2018).

Fox, Ben. 2018. US Military Plans for Future at Guantanamo Because of Trump. AP News, June 7. Available online: https:/ / www.apnews.com/ca3a339b1ada4f229310a2bcd483fd81/US-military-plans-forfuture-at-Guantanamo-because-of-Trump (accessed on 29 July 2018).

Global Fund For Women. 2017. 9 Inspiring Muslim Women Shattering Stereotypes. Global Fund For Women, June 29. Available online: https:/ / www.globalfundforwomen.org/9-inspiring-muslim-women-shatteringstereotypes/\#.W14E4NJKjIV (accessed on 29 July 2018).

Gray, Noah, and Mj Lee. 2015. Trump to CNN: 'I love the Muslims'. CNN Politics, September 20. Available online: https:/ / www.cnn.com/2015/09/19/politics/donald-trump-muslims-controversy/index.html (accessed on 29 July 2018).

Green, Emma. 2017. How America Is Transforming Islam. December 31. Available online: https:/ /www.theatlantic. com/politics/archive/2017/12/muslims-assimilation-weddings/549230/ (accessed on 29 July 2018).

Haines, Avery. 2015. Toronto Woman Assaulted after Her Scarf Is Mistaken for Hijab. City News Toronto, November 20. Available online: https:/ / toronto.citynews.ca/2015/11/20/toronto-woman-assaulted-afterher-scarf-is-mistaken-for-hijab / (accessed on 29 July 2018).

Hill, Margari. 2015a. Study of Intra-Muslim Ethnic Relations: Muslim American Views on Race Relations. Available online: http:/ / www.muslimarc.org/interethnic/ (accessed on 6 September 2018).

Hill, Margari. 2015b. What's In a Name?: Using "Muslim" as a Cultural Category Erases and Stereotypes. Muslim ARC, May 13. Available online: http://www.muslimarc.org/whats-in-a-name/ (accessed on 29 July 2018).

Islam, Namira. 2018a. An anti-Muslim narrative has shaped policy for decades. The travel ban will make it worse. Vox Media, June 27. Available online: https:/ / www.vox.com/first-person/2018/6/27/17510560/travelban-muslim-trump-islamophobia (accessed on 29 July 2018).

Islam, Namira. 2018b. Build with the People Who Love You. April 23. Available online: https://medium.com/ @namira.islam/build-with-the-people-who-love-you-a42943bbe04c (accessed on 29 July 2018).

Islam, Namira. 2018c. Modifying Silk Ring Theory for Allyship. April 16. Available online: https://medium.com/ @namira.islam/modifying-silk-ring-theory-for-allyship-c7ae4963912d (accessed on 29 July 2018).

Jacobson, Louis. 2018. Is Mike Pence Right That Religion Is Gaining New Life in US? PolitiFact, May 16. Available online: https://www.politifact.com/truth-o-meter/statements/2018/may/16/mike-pence/mikepence-right-religion-gaining-new-life-us / (accessed on 29 July 2018). 
Jenkins, Jacobson. 2017. Nobody is Laughing at the Religious Left in 2017. Think Progress, December 13. Available online: https:/ thinkprogress.org/2017-is-the-year-trump-and-the-religious-right-made-thereligious-left-unavoidable-3e89528104b6/ (accessed on 29 July 2018).

Kaleem, Jaweed. 2017. At the nation's only Latino mosque, Trump's immigration policies have 'changed everything'. Los Angeles Times, March 10. Available online: http:/ / www.latimes.com/nation/la-na-latinomuslims-2017-story.html (accessed on 29 July 2018).

Khalil, Yameen. 2014. Christmas, Ramadan: Holidays with Similarities. Tulsa World, June 28. Available online: http: / / muslimwriters.org/2014/06/28/christmas-ramadan-holidays-with-similarities/ (accessed on 29 July 2018).

Khan, Sidrah Moiz. 2012. The Rise of the Hijabista. The Express Tribune, November 19. Available online: https: / tribune.com.pk/story /466267/the-rise-of-the-hijabista/ (accessed on 29 July 2018).

Kid, T. 2013. A Muslim's Adventures in Pork. Vice Media LLC, September 22. Available online: https: / /www. vice.com/en_us/article/exm4zp/a-muslims-adventures-in-pork (accessed on 29 July 2018).

Kloub, Mohammed. 2016. Yes, there is such a thing as a secular Muslim. The Seattle Globalist, March 30. Available online: http:/ /www.seattleglobalist.com/2016/03/30/secular-muslim-non-practicing-islamreligion-kloub/47754 (accessed on 14 September 2018).

Krugman, Paul. 2017. The Conscience of a Liberal. New York: W. W. Norton.

Lind, Dara. 2016. Donald Trump's Proposed "Muslim Registry", Explained. Vox, November 16. Available online: https: / /www.vox.com/policy-and-politics/2016/11/16/13649764/trump-muslim-register-database (accessed on 29 July 2018).

Lipka, Michael. 2015. The Most and Least Racially Diverse U.S. Religious Groups. Pew Research Center. Available online: http:/ / www.pewresearch.org/fact-tank/2015/07/27/the-most-and-least-racially-diverseu-s-religious-groups / (accessed on 6 September 2018).

Maiese, Michelle. 2003. Dehumanization. (The Beyond Intractability Project). Beyond Intractability, July. Available online: https:/ / www.beyondintractability.org/essay/dehumanization (accessed on 29 July 2018).

Mallenbaum, Carly. 2017. 'Master of None': Aziz Ansari opens up about his Muslim upbringing. USA Today, May 17. Available online: https:/ / www.usatoday.com/story/life/entertainthis/2017/05/17/master-ofnone-aziz-ansari-muslim/101693552/ (accessed on 29 July 2018).

Mamdani, Mahmood. 2002. Good Muslim, Bad Muslim: A Political Perspective on Culture and Terrorism. American Anthropologist 104: 766-775. Available online: https://islamophobiaisracism.files.wordpress. com/2017/03/mamdani-good-muslim-bad-muslim-2002-american_anthropologist.pdf (accessed on 14 September 2018).

McCrummen, Stephanie. 2017. 'Love Thy Neighbor?'. The Washington Post, July 1. Available online: https: / www.washingtonpost.com/national/in-a-midwestern-town-that-went-for-trump-a-muslimdoctor-tries-to-understand-his-neighbors / 2017/07/01/0ada50c4-5c48-11e7-9fc6-c7ef4bc58d13_story. html?noredirect=on\&utm_term=.763b391af250 (accessed on 29 July 2018).

McPhail, Mark. 2002. The Rhetoric of Racism Revisited: Reparations or Separation? Lanham: Rowman and Littlefield Publishers, Inc.

Mohdin, A. 2017. Trump Plans to Block Visas from Seven Muslim-Majority Countries. The US Is Currently Bombing Five of Them. Quartz, January 26. Available online: https://qz.com/895516/which-countries-isthe-us-currently-bombing / (accessed on 29 July 2018).

Müller, Karsten, and Carlo Schwarz. 2018. Making America Hate Again? Twitter and Hate Crime Under Trump. March 30. Available online: https:/ / ssrn.com/abstract=3149103 or http:/ / dx.doi.org/10.2139/ssrn.3149103 (accessed on 15 September 2018).

MuslimARC. 2014. \#BlackLivesMatter Toolkit for Muslims. Muslim Anti-Racism Collaborative, December 15. Available online: http:/ / www.muslimarc.org/blacklivesmatter/ (accessed on 29 July 2018).

MuslimARC. 2016. Indigenous Peoples' Campaign. Muslim Anti-Racism Collaborative, September 30. Available online: http:/ / www.muslimarc.org/indigenous (accessed on 29 July 2018).

Nomani, Asra. 2015. As Muslim women, we actually ask you not to wear the hijab in the name of interfaith solidarity. The Washington Post, December 21. Available online: https:/ / www.washingtonpost.com/news/acts-of-faith/ wp/2015/12/21/as-muslim-women-we-actually-ask-you-not-to-wear-the-hijab-in-the-name-of-interfaithsolidarity /?utm_term=.4d6c59278782 (accessed on 14 September 2018). 
NPR. 2018. 'Flying While Muslim': Profiling Fears After Arabic Speaker Removed from Plane. February 2. Available online: https:/ / www.npr.org/2016/04/20/475015239/flying-while-muslim-profiling-fears-afterarabic-speaker-removed-from-plane (accessed on 6 September 2018).

OSCE. 2017. Hate Crime against Muslims. Warsaw: Office for Democratic Institutions and Human Rights.

Page, Julia. 2018. Videos of fatal mosque attack show shooter reload as victims seek cover. CBC/Radio-Canada, April 5. Available online: http://www.cbc.ca/news/canada/montreal/alexandre-bissonnette-sentencing-1.4605036 (accessed on 29 July 2018).

Pew Research Center. 2017. 2017 Survey of U.S. Muslims. Available online: http:/ / www.pewforum.org/2017/07/ 26/demographic-portrait-of-muslim-americans / (accessed on 6 September 2018).

Posner, Saran. 2011. Welcome to the Shari'ah Conspiracy Theory Industry. Religion Dispatches, March 8. Available online: http://religiondispatches.org/welcome-to-the-shariah-conspiracy-theory-industry/ (accessed on 29 July 2018).

Rainer, Thomas. 2007. Ten Surprises about the Unchurched. Christianity Today, July. Available online: https: / / www.christianitytoday.com/pastors/2007/july-online-only/102704.html (accessed on 29 July 2018).

Rifai, Ryan. 2016. Report: Islamophobia Is a multimillion-Dollar Industry. Al Jazeera, June 24. Available online: https://www.aljazeera.com/indepth/features/2016/06/report-islamophobia-multimillion-dollar-industry-160623144006495.html (accessed on 29 July 2018).

Rosario, Justin. 2017. Anti-Muslim Bigot Attacks “Terrorist” Latino Family with Baseball Bat. The Daily Banter, December 11. Available online: https:/ / thedailybanter.com/issues/2017/12/11/anti-muslim-bigot-attacksterrorist-latino-family-with-baseball-bat/ (accessed on 6 September 2018).

Rozen, Courtney. 2017. Ramadan Is Major Time for Charitable Donations in DC. NBC Washington, June 23. Available online: https:/ / www.nbcwashington.com/entertainment/the-scene/Donations-From-DC-AreaMuslims-Power-Local-Charities-During-Ramadan-430414353.html (accessed on 29 July 2018).

Safi, Michael. 2017. Rise of Hindu 'Extremist' Spooks Muslim Minority in India's Heartland. The Guardian, March 25. Available online: https://www.theguardian.com/world/2017/mar/26/modis-man-flexesmuscular-hinduism-shock-election (accessed on 29 July 2018).

Salam, Maya. 2018. Party City Offers Ramadan Decorations, a First for a Big U.S. Retailer. The New York Times, April 20. Available online: https://www.nytimes.com/2018/04/20/business/ramadan-party-citydecorations.html (accessed on 29 July 2018).

Saleh, Maryam. 2018. ICE Detention Center Is Creating Obstacles to Ramadan Observance for Muslim Detainees, Lawyers Say. The Intercept, June 7. Available online: https:/ theintercept.com/2018/06/07/ice-immigrationdetention-ramadan-religious-accomodation / (accessed on 26 July 2018).

Sanchez, Olivia. 2017. Five 'Badass Muslim Women' Tell Their Stories. The Portland Tribune, August 3. Available online: https:/ / portlandtribune.com/pt/9-news/368047-248115-telling-their-story (accessed on 29 July 2018).

Sanghani, Radhika. 2016. How the hijab went high-fashion and divided Muslim women. The Telegraph. (Telegraph Media Group), February 18. Available online: https://www.telegraph.co.uk/women/life/how-the-hijabwent-high-fashion-and-divided-muslim-women/ (accessed on 14 September 2018).

Scholastic. n.d. Nativism in America and Europe. Scholastic. Available online: https://www.scholastic.com/ teachers/articles/teaching-content/nativism-america-and-europe/ (accessed on 29 July 2018).

Shaheen, Jack. 2014. Reel Bad Arabs: How Hollywood Vilifies a People. Northhampton, Massachusetts: Interlink.

Shukla, Sebastian. 2016. Muslim Woman to Appear in Playboy in a Hijab. CNN, September 28. Available online: https:/ / www.cnn.com/style/article/playboy-hijabi-woman-trnd/index.html (accessed on 29 July 2018).

Soubry, Anna, and Wes Streeting. 2017. The Difference Made by Muslim Charities Is Often Ignored-Especially over Christmas. The Independent, December 19. Available online: https:/ / www.independent.co.uk/voices/ muslim-charity-charities-christmas-homelessness-volunteer-a8117116.html (accessed on 29 July 2018).

Sidahmed, Mazin. 2016. Hundreds at New York mosque mourn woman murdered in 'hate crime'. The Guardian, September 3. Available online: https:/ / www.theguardian.com/us-news/2016/sep/03/new-york-muslimmurder-bangladeshi-nazma-khanam (accessed on 29 July 2018).

Solis, Marcus. 2016. Cab driver beaten by passenger in the Bronx speaks out. ABC Inc., May 24. Available online: http:/ /abc7ny.com/news/cab-driver-beaten-by-passenger-in-the-bronx-speaks-out/1353811 (accessed on 29 July 2018). 
Strathern, A. 2013. Why Are Buddhist Monks Attacking Muslims? BBC News, May 2. Available online: https: / / www.bbc.com/news/magazine-22356306 (accessed on 29 July 2018).

The Caribbean Camera Inc. 2015. Non-Muslim Suffers Islamaphobic Attack. The Caribbean Camera, November 25. Available online: http:/ / www.thecaribbeancamera.com/community-events/non-muslim-suffers-islamaphobicattack/ (accessed on 29 July 2018).

UNESCO. n.d. Xenophobia; United Nations Educational, Scientific, and Cultural Organization. Available online: http:/ / www.unesco.org/new/en/social-and-human-sciences/themes/international-migration/glossary/ xenophobia / (accessed on 29 July 2018).

War On Want. 2015. Sweatshops in Bangladesh. War On Want, June 23. Available online: https://waronwant.org/ sweatshops-bangladesh (accessed on 29 July 2018).

Warikoo, Niraj. 2017. At Ramadan, Group Pushes Positive Images of Muslims. Detroit Free Press, May 26. Available online: https:/ /www.freep.com/story/news/2017/05/26/new-report-says-muslims-michigancontribute-lot-medicine-business-politics/332800001/ (accessed on 29 July 2018).

Washington University Digital Library. 1988. Interview with Mike Wallace. (W. U. Texts, Interviewer). October 12. Available online: http:/ / digital.wustl.edu/e/eii/eiiweb /wal5427.0729.168mikewallace.html (accessed on 6 September 2018).

Watson Institute for International \& Public Affairs. n.d. Civilians Killed and Wounded; Watson Institute Costs of War. Available online: https:// watson.brown.edu/costsofwar/costs/human/civilians (accessed on 29 July 2018).

Weiner, Zoe. 2017. How 16 Hijabi Women Use Makeup to Express Themselves. Bustle, May 22. Available online: https: / www.bustle.com/p/how-16-hijabi-women-use-makeup-to-express-themselves-39355 (accessed on 29 July 2018).

Wright, Robin. 2016. Humayun Khan Isn't the Only Muslim American Hero. The New Yorker, August 15. Available online: https:/ /www.newyorker.com/news/news-desk/humayun-khan-isnt-the-only-muslimamerican-hero (accessed on 29 July 2018).

(C) 2018 by the author. Licensee MDPI, Basel, Switzerland. This article is an open access article distributed under the terms and conditions of the Creative Commons Attribution (CC BY) license (http:// creativecommons.org/licenses/by/4.0/). 